\title{
EVALUATION OF ORAL CANCER AWARENESS LEVEL OF FACULTY OF DENTISTRY STUDENTS AND ACADEMICIANS
}

\section{DİŞ HEKİMLİĞİ FAKÜLTESİ ÖĞRENCİLERİ VE ÖĞRETİM ÜYELERİNDE ORAL KANSER FARKINDALIK DÜZEYİNİN DEĞERLENDİRİLMESİ}

\author{
Dr. Gurbet Alev ÖZTAŞ* \\ Dr. Öğr. Üyesi Tuğba AYDIN* \\ Arş. Gör. Dt. Ahmet Bedreddin ŞAHİ**
}

Makale Kodu/Article code: 4876

Gurbet Alev Öztaş: ORCID ID: 0000-0002-0565-6194

Makale Gönderilme tarihi: 18.02 .2021

Tuğba Aydın: ORCID ID: 0000-0002-9675-5509

Kabul Tarihi: 02.06.2021

Ahmet Bedreddin Şahin: ORCID ID: 0000-0002-4742-9627

DOI: $10.17567 /$ ataunidfd.947037

\section{ABSTRACT}

Aim: Oral cancers are neoplasms that occur in the lips or oral cavity. The knowledge and awareness of dentists is very important in its prevention and early diagnosis. In this study, it was aimed to evaluate the awareness and to measure knowledge level about oral cancers among the intern dentists, research assistants and academicians in Atatürk University Faculty of Dentistry in Erzurum

Materials and Methods: Participants were directed to closed-ended questions developed using questionnaires that previously evaluated oral cancers awareness. The questionnaire consists of 32 questions to evaluate oral cancer awareness.

Results: 80 females and 60 males, totally 140 participants of which 53 are intern dentists, 51 research assistants and 36 academicians from 8 different departments at the Faculty of Dentistry, were included in the study. When asked about the competence of knowledge and skills in the evaluation of oral lesions, $30 \%$ of the participants stated themselves as sufficient. The academicians in the Departments of Oral and Maxillofacial Surgery, Oral Diagnosis and Radiology and Periodontology, respectively, stated that they consider themselves competent in awareness of oral cancer in a statistically significant way. Candida albicans, ultraviolet rays, thermal irritation, chronic oral traumas, viral infections such as HPV, white and red mouth lesions were evaluated as risk factors by more than $90 \%$ of the participants.

Conclusion: Only one third of the participants think that they are adequately trained in oral cancer examination. This situation should be evaluated and efforts should be made to raise awareness.

Keywords: awareness; knowledge; mouth neoplasms; risk factors; survey

öz

Amaç: Oral kanserler, dudak veya ağız boşluğunda ortaya çıkan neoplazilerdir. Önlenebilmesi ve erken teşhisinde diş hekimlerinin bilgi ve farkındalığı çok önemlidir. Bu çalışmada Atatürk Üniversitesi Diş Hekimliği Fakültesi'nde bulunan stajyer diş hekimlerinin, araştırma görevlilerinin ve öğretim üyelerinin oral kanserler ile ilgili farkındalıklarının değerlendirilmesi ve bilgi düzeylerinin ölçülmesi amaçlanmıştır.

Gereç-Yöntem: Katılımcılara, daha önce oral kanserler farkındalığının değerlendirildiği anketlerden faydalanılarak geliştirilmiş kapalı uçlu sorular yönlendirilmiştir. Anket, oral kanser farkındalığının değerlendirildiği 32 sorudan oluşmaktadır.

Bulgular: Çalışmaya 80 kadın, 60 erkek toplamda 140 kişi dahil edilmiştir. Katılımcıların 53'ü stajyer diş hekimi, 51'i araştırma görevlisi ve 36'sı öğretim üyesidir. Araştırmaya 8 anabilim dalından katılımcı mevcuttur. Oral lezyonların değerlendirilmesinde bilgi ve beceri yeterliliği sorulduğunda, katılımcıların \%30'u kendilerini yeterli olarak belirtmiştir. Sırası ile Ağız Diş ve Çene Cerrahi, Oral Diagnoz ve Radyoloji ve Periodontoloji alanlarındaki öğretim üyeleri istatistiksel olarak anlamlı oranda kendilerini yeterli gördüklerini belirtmiștir. Candida albicans, ultraviyole ışınlar, termal irritasyon, kronik oral travmalar, HPV gibi viral enfeksiyonlar, beyaz ve kırmızı ağız lezyonları, katıımcıların \%90'ından fazlası tarafından risk faktörü olarak değerlendirilmiştir. Sonuç: Katılımcların sadece üçte biri oral kanser muayenesi konusunda yeterince eğitimli olduklarını düşünmektedir. Bu durum değerlendirilmeli ve farkındalığın arttırıması için çalışmalar yapılmalıdır.

Anahtar Kelimeler: ağız kanseri; bilgi; farkındalık; risk faktörleri; anket

\footnotetext{
${ }^{*}$ Ataturk University Faculty of Dentistry Department of Periodontology, Erzurum.
}

Kaynakça Bilgisi: Öztaș GA, Aydın T, Şahin AB. Diş hekimliği fakültesi öğrencileri ve öğretim üyelerinde oral kanser farkındalık düzeyinin değerlendirilmesi. Atatürk U̧niv Diş Hek Fak Derg 2021; 31: 367-72.

Citation Information: Oztas GA, Aydin T, Sahin AB. Evaluation of oral cancer awareness level of faculty of dentistry students and academicians. J Dent Fac Citation Information: Oztas
Atatürk Uni 2021; 31: 367-72.. 


\section{INTRODUCTION}

Oral cancers are diseases with low awareness in the society, progressing quietly and can be life threatening. It is very important to carefully examine patients who apply to dentists with different dental and gingival problems affecting the oral area, if they have complaints and etiological factors. Awareness and level of knowledge of the patient and dentist are very important in this regard.

Cancers arise due to mutations in genes that modify cell proliferation, cell differentiation, and cell death. ${ }^{1}$ Oral cancers are malignant neoplasms that occur in the lips or oral cavity. $90 \%$ of oral cancers arise histologically from squamous cells. ${ }^{2}$ The remaining $10 \%$ are in rare forms of small salivary gland tumors, lymphoma, sarcoma, and melanoma. ${ }^{3}$ It has been reported that oral cancers are the $6^{\text {th }}$ most common type of cancer and are frequently seen in middle-aged and elderly individuals. ${ }^{4}$ However, a significant number of these malignancies have been detected in young adults in recent years. ${ }^{5-7}$ It has been reported that there is a steady increase in oral cancer and pharyngeal cancer mortality rates for young men in Eastern Europe. ${ }^{8}$

Smoking and alcohol use is present in $90 \%$ of oral cancer cases. ${ }^{9}$ Studies have shown that chewing tobacco is associated with oral cancer and precancerous lesions (leukoplakia, erythroplakia, and oral submucous fibrosis). ${ }^{10}$ It has been emphasized that mouthwashes containing alcohol can also cause oral cancer. ${ }^{11}$ Human Papilloma Virus (HPV) has been found to be associated with some oral and oropharyngeal cancers. ${ }^{12,13}$ The relationship between diet and nutrition and the risk of developing cancer has been shown by various epidemiological and laboratory studies. The International Agency for Research on Cancer (IARC) has confirmed that low intake of fruits and vegetables (particularly carrots, tomatoes and green peppers) increases the risk of developing cancer. ${ }^{14}$

Although the oral cavity is easily accessible during clinical examination, oral cancers can usually be diagnosed at advanced stages. The most common reasons for this are insufficient knowledge of the patient or dentist or inadequate initial examination and misdiagnosis. ${ }^{15}$ In oral squamous cell carcinoma (OSCC) patients, the treatment rate of patients diagnosed in the first stage is $80 \%$, and the treatment rate of patients diagnosed in the second stage is $65 \%$, and a good prognosis is expected for these patients. ${ }^{16}$ Unfortunately, most cases are diagnosed in advanced stages (stage III or IV) of the disease, ${ }^{17}$ and the 5year survival rate of this group of patients is less than $50 \% .^{18}$ Untreated patients with metastases show a survival of approximately 4 months. ${ }^{17}$

Knowing the risk factors for oral cancers, evaluating and informing the patients examined in line with these factors, and making periodic examinations of the patients in the high risk group are among the responsibility of the dentist. However, in studies conducted in various countries, it was determined that students and dentists of the faculty of dentistry do not regularly apply the procedures for the prevention and early diagnosis of oral cancers. ${ }^{19-22}$

In this study, it was aimed to evaluate the awareness and to measure their knowledge level about oral cancers among the intern dentists, research assistants and academicians in Atatürk University Faculty of Dentistry in Erzurum

\section{Material and Method}

This study was carried out with voluntary selected intern dentists, research assistants and academicians at Atatürk University Faculty of Dentistry between September and October 2020. Ethical approval for the study was obtained from Atatürk University Faculty of Dentistry. Participants were directed to closed-ended questions to evaluate oral cancer awareness. Information on the variety of questions is presented in Table 1.

Table 1. Diversity distribution of survey study questions

\begin{tabular}{lc}
\hline question content & number of questions \\
\hline Demographic information & 4 \\
Knowledge of oral cancer risk factors & 12 \\
Knowledge about oral cancer diagnosis & 5 \\
procedures & \\
Anamnesis and attitude & 11 \\
Sources of information & 4 \\
Total & 36 \\
\hline
\end{tabular}

All questionnaires were conducted with face-toface communication with the participants by the same researcher. In line with the answers received from the participants, the results; in order to investigate the oral cancer knowledge level and the effect of demographic factors on these responses, they were grouped according to their education level.

The data were analyzed using the IBM Statistical Program for Social Sciences (SPSS) Statistics $22.0 \circledR$ software. The statistical distribution of the data 
has been examined. Chi-square $\mathrm{x} 2$ test was used to evaluate categorical data between groups. All evaluations were made at $95 \%$ confidence level and were evaluated at $5 \%$ significance level.

Table 2. The number of participants in different groups.

\begin{tabular}{lc}
\hline Groups & Number of participants \\
\hline Intern dentists & 53 \\
Research assistant dentist & 51 \\
Academicians & 36 \\
Total & 140 \\
\hline
\end{tabular}

Table 3. The number of participants by academic departments

\begin{tabular}{lccc}
\hline Groups & $\begin{array}{c}\text { Number of } \\
\text { research assistant } \\
\text { participants }\end{array}$ & $\begin{array}{c}\text { Number of } \\
\text { Academicians } \\
\text { participants }\end{array}$ & Total \\
\hline Oral and maxillofacial surgery & 10 & 2 & 12 \\
Orthodontics & 11 & 1 & 12 \\
Restorative & 10 & 2 & 12 \\
Periodontology & 8 & 3 & 11 \\
Pedodontics & 8 & 3 & 11 \\
Prosthodontics & 8 & 2 & 10 \\
Endodontics & 8 & 2 & 10 \\
Oral Diagnosis and Radiology & 7 & 2 & 9 \\
Total & 70 & 17 & 87 \\
\hline
\end{tabular}

\section{RESULTS}

80 females and 60 males, totally 140 participants from 8 different departments at the Faculty of Dentistry were included in the study. The education level of the participants and the distribution of the academic departments are shown in Table 2 and Table 3.

When the answers given by the participants to the questions evaluating their knowledge about oral cancer risk factors were examined, tobacco use and tobacco chewing habit were defined as risk factors by $100 \%$ of the participants. Candida albicans, ultraviolet rays, thermal irritation, chronic oral traumas, viral infections such as HPV, white and red mouth lesions were evaluated as risk factors by more than $90 \%$ of the participants.

Low fruit and vegetable consumption was evaluated as a risk factor by $61 \%$ of the participants. Although this rate was $67 \%$ among the academicians, it did not create a statistically significant difference ( $p>0.05)$.

When asked about the competence of knowledge and skills in evaluating oral lesions and lymph nodes in terms of oral cancer risk, 30\% of the participants stated themselves as sufficient, but $46 \%$ as insufficient. Research assistants and academicians at the Departments of Oral and Maxillofacial Surgery, Oral Diagnosis and Radiology and Periodontology, respectively, stated that they consider themselves competent at a statistically significant rate. On the other hand, research assistants and academicians in the field of Prosthodontics, rated themselves as inadequate at a rate of $63 \%$.

As the intraoral region where oral cancers are most common, $52 \%$ of the participants evaluated the floor of the mouth and the posterolateral of the tongue. $22 \%$ of the participants stated that oral cancers are more common in the lower lip, and $8 \%$ in hard and soft tissue.

$84 \%$ of the participants evaluated that oral cancers were the most common type of squamous cell carcinoma and $8 \%$ of them were basal cell carcinoma.

The results evaluated by the participants as the etiological factors of cancer are given in Figure 1. It was observed that research assistants and academicians in the fields of Oral and Maxillofacial Surgery and Oral Diagnosis and Radiology were statistically significantly more effective in evaluating the history of alcohol and cancer $(p<0.05)$.

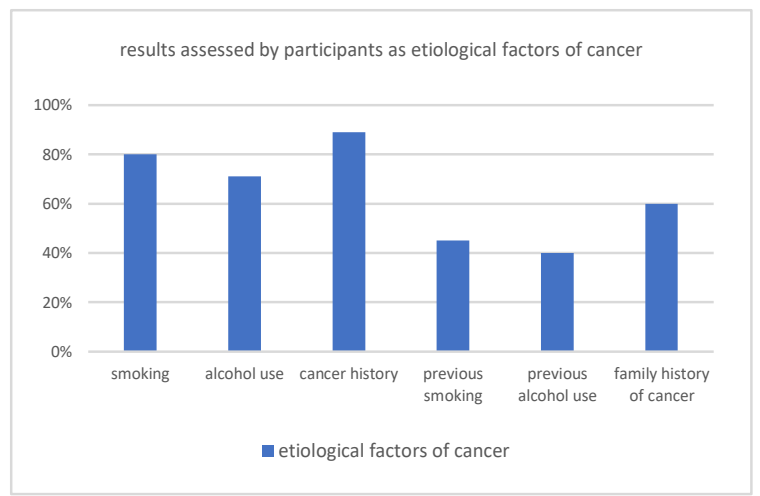

Figure 1. The results evaluated by the participants as the etiological factors of cancer

$92 \%$ of the participants stated that their knowledge about oral cancer diagnosis and treatment was from undergraduate education. All of the research assistants and academicians in the fields of Oral and Maxillofacial Surgery and Oral Diagnosis and Radiology stated that they conducted regular article reviews on oral cancers $(p<0,05)$.

Considering their participation in dentistry congresses, it was learned that $75 \%$ of the participants of research assistants and academicians in the fields of Oral Diagnosis and Radiology, Prosthodontics and

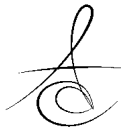


Pedodontics were able to participate. $27 \%$ of the participants of the research assistants and academicians in the field of orthodontics stated that they attended congresses in the field of dentistry at least.

\section{DISCUSSION}

This survey study was conducted to evaluate awareness for oral cancer information and diagnosis. The results indicated that only one third of the intern dentists, research assistants and academicians in Atatürk University Faculty of Dentistry think that they are adequately trained in oral cancer examination. In the clinical examination of the patients, it was determined that oral cancer risk factors were evaluated by physicians at the anamnesis stage.

The study was carried out with 140 participants in Atatürk University Faculty of Dentistry. The sample size of the study could not reach sufficient numerical values in line with the students and academicians who could not continue the education period due to the measures taken during the Covid-19 pandemic period. However, it is thought that this distribution can reflect the general tendency of dentists of Atatürk University Faculty of Dentistry. And, it was paid attention that the number of participants of the dentistry departments were similar to each other.

Outside skin and thyroid cancer, oral cavity cancer (OCC) after laryngeal carcinomas are considered to be the second most common malignancy of the head and neck in Turkey. ${ }^{23}$ Squamous cell carcinoma was also found to be the most common histopathological type in all oral cavity sites except the hard palate. ${ }^{24}$ In an epidemiological study conducted in Turkey it was reported that oral cancer was more common in female patients than male patients. Cancer findings have been reported mostly in the tongue $(39 \%)$, oropharynx-tonsil $(16 \%)$, floor of the mouth $(15 \%)$, buccal gingiva (9\%) and retromolar regions (5\%). ${ }^{25}$

Early stage oral cancers and precancerous lesions are often asymptomatic, so the dentist should have a high suspicion, especially in patients with risk factors such as tobacco use or alcohol use. Clinically identifiable premalignant changes in the oral mucosa are seen before oral squamous cell carcinoma. These lesions are usually present as white or red spots known as leukoplakia and erythroplakia. ${ }^{26}$ The most common oral precancerous lesions are oral leukoplakia, oral submucous fibrosis (OSMF), and oral erythroplakia. ${ }^{27,28}$ Mortality of oral cancers that cannot be diagnosed at an early stage is reported to be high. ${ }^{4}$ In this respect, clinical and radiographic examinations of dentists are an important step for early diagnosis. It is very important to know oral cancer risk factors and to identify individuals in the risk group. Most of the dentists participating in the study were able to identify the risk factors. In similar studies evaluating oral cancer awareness, participants were evaluated as knowledgeable about cancer risk factors. ${ }^{20,29,30}$ Yellowitz et al. ${ }^{29}$ determined the average oral cancer risk score information as 8.4 and stated that this score is sufficient for dentists in oral cancer knowledge. However, it has also been reported that they are not knowledgeable enough about cancer prevention and early diagnosis.

Another important point in the evaluation of the patient in terms of oral cancer is the examination of the lymph nodes. However, $30 \%$ of the participants in our study think that they have sufficient information to perform and evaluate lymph node examination. Horowitz et al. ${ }^{19}$ determined this rate was $35 \%$, and, Erbaşar and Alpaslan ${ }^{30}$ is determined as one third in their studies. The reasons such as insufficient education of dentists in undergraduate and postgraduate education and not keeping up-to-date information may cause this situation. $92 \%$ of the participants stated that they got their knowledge about the subject from undergraduate education, but only one third of them considered themselves sufficient. Similarly, in a study conducted in England, $41 \%$ of dentists stated that their undergraduate education is insufficient in identifying oral cancer. ${ }^{31}$ All of the research assistants and academicians in the fields of Oral and Maxillofacial Surgery and Oral Diagnosis and Radiology stated that they conducted regular article reviews on oral cancers. It is very important for physicians to follow current studies on related issues in the diagnosis and treatment of diseases.

$35 \%$ of the dentists participating in the study stated that they attended training courses on oral cancers. It is stated that benefiting from scientific journals and articles is $67 \%$, and participation to dental congresses is $49 \%$. In their studies, Erbaşar et al. ${ }^{30}$ stated that $41.5 \%$ of the participants did not attend any training on oral cancers after their undergraduate education, and $60 \%$ stated that they were interested in studies on the subject. Completion of training is required for the prevention and early 
diagnosis of oral cancers as part of dental education in New York State. ${ }^{32}$ Educational activities will ensure awareness raising and giving the necessary importance to oral cancers.

In order to improve the diagnosis and treatment of oral cancers, the awareness of patients and physicians should be increased. In a study, it was determined that individuals with high oral health awareness benefit better from health services. ${ }^{33}$ The adequacy of the information provided in the undergraduate program should be evaluated. By encouraging dentists working in universities and public institutions to participate in education regularly, increasing knowledge and awareness will reduce mortality and morbidity with early diagnosis.

\section{MainPoints}

The knowledge and awareness of dentists is very important in its prevention and early diagnosis.

Only one third of the dentists participating in the study think they are adequately trained in oral cancer examination.

This situation should be evaluated and efforts should be made to raise awareness.

\footnotetext{
Here the authors declare that;

- None of the authors of this article has any relationship, connection or financial interest with respect to the subject or material mentioned in the article,

- Any part of this work has not been published or submitted for publication elsewhere,

- The manuscript has been read and approved by all the authors.
}

\section{REFERENCES}

1. Davies $H$, Bignell GR, Cox $C$, et al. Mutations of the BRAF gene in human cancer. Nature 2002; 417: 949-54.

2. Lingen MW, Kalmar JR, Karrison $\mathrm{T}$, et al. Critical evaluation of diagnostic aids for the detection of oral cancer. Oral Oncol 2008; 44: 10-22.

3. Genden E M, Ferlito A, Silver $C E$, et al. Contemporary management of cancer of the oral cavity. Eur Arch Otorhinolaryngol 2010; 267: 100117.

4. Warnakulasuriya S. Global epidemiology of oral and oropharyngeal cancer. Oral Oncol 2009; 45: 309-16.

5. Chen J, Katz RV, Krutchkoff DJ. Intraoral squamous cell carcinoma: epidemiologic patterns in Connecticut from 1935 to 1985 . Cancer 1990; 66: 1288-96.

6. Llewellyn C, Johnson N, Warnakulasuriya K. Risk factors for squamous cell carcinoma of the oral cavity in young people-a comprehensive literature review. Oral Oncol 2001; 37: 401-18.

7. Schantz SP, Yu GP. Head and neck cancer incidence trends in young Americans, 1973-1997, with a special analysis for tongue cancer. Arch Otolaryngol Head Neck Surg 2002; 128: 268-74.

8. Jané-Salas E, Chimenos-Küstner E, López-López J, et al. Importance of diet in the prevention of oral cancer. Med Oral Patol Oral Cir Bucal 2003; 8: 26068.

9. Dissanayaka WL, Pitiyage G, Kumarasiri PVR, et al. Clinical and histopathologic parameters in survival of oral squamous cell carcinoma. Oral Surg Oral Med Oral Pathol Oral Radiol 2012; 113: 51825.

10. Axéll T. Occurrence of leukoplakia and some other oral white lesions among 20333 adult Swedish people. Community Dent Oral Epidemiol 1987; 15: 46-51.

11. McCullough, MJ, and Farah CS. The role of alcohol in oral carcinogenesis with particular reference to alcohol-containing mouthwashes. Aust Dent J 2008; 53: 302-5.

12. Miller CS, White DK. Human papillomavirus expression in oral mucosa, premalignant conditions, and squamous cell carcinoma: a retrospective review of the literature. Oral Surg Oral Med Oral Pathol Oral Radiol 1996; 82: 57-68.

13. Mork J, Lie AK, Glattre E, et al. Human papillomavirus infection as a risk factor for squamous-cell carcinoma of the head and neck. N Engl J Med 2001; 344: 1125-31.

14. Jeng $\mathrm{J}-\mathrm{H}$, Chang $\mathrm{M}$, Hahn L. Role of areca nut in betel quid-associated chemical carcinogenesis: current awareness and future perspectives. Oral Oncol 2001; 37: 477-492.

15. Markopoulos AK. Current aspects on oral squamous cell carcinoma. Open Dent J. 2012; 6: 126.

16. Güneri $P$, Epstein JB. Late stage diagnosis of oral cancer: components and possible solutions. Oral Oncol 2014; 50: 1131-36.

17. Kowalski LP, Carvalho AL. Natural history of untreated head and neck cancer. Eur J Cancer 2000; 36: 1032-37.

18. Viet C, Schmidt B. Biologic mechanisms of oral cancer pain and implications for clinical therapy. J Dent Res 2012; 91: 447-53.

19. Horowitz AM, Drury TF, Goodman HS, et al. Oral 
ÖZTAŞ, AYDIN, ŞAHIN

pharyngeal cancer prevention and early detection: dentists' opinions and practices. JADA 2000; 131: 453-62.

20. Razavi SM, Zolfaghari B, Foroohandeh $M$,et al. Dentists' knowledge, attitude, and practice regarding oral cancer in Iran. J Cancer Educ 2013; 28: 335-41.

21. Ferlay J, Soerjomataram I, Dikshit R, et al. Cancer incidence and mortality worldwide: sources, methods and major patterns in GLOBOCAN 2012. Int Cancer 2015; 136: 359-86.

22. Hasanoğlu Erbaşar GN, Alpaslan C. Oral cancer prevention and early detection awareness of Ankara dentists. Acta Oncol Tur. 2017; 50: 139-47.

23. Başak K, Sağlam Y, Yıldız AG, et al. Profile of Head and Neck Cancers in Dr. Lütfi Kırdar Kartal Educational and Research Hospital/Dr. Lütfi Kırdar Kartal Eğitim ve Araştırma Hastanesi Baş Boyun Kanserleri Profili. Turk J Pathol 2015; 31: 119-25.

24. Düzlü $M$, Karamert $R$, Bakkal FK, et al. The demographics and histopathological features of oral cavity cancers in Turkey. Turk J Med Sci 2016; 46: 1672-76.

25. Midilli R, Akyildiz $S$, Yavuzer A, et al. In Oral Kanserli 231 Hastanin Epidemiyolojik Özelliklerinin Retrospektif Analizi, KBB-Forum-Elektronik 2005; pp 4-7.

26. Neville BW, Day TA. Oral cancer and precancerous lesions. CA Cancer J Clin. 2002; 52: 195-215.

27. Thomas G, Hashibe M, Jacob BJ, et al. Risk factors for multiple oral premalignant lesions. Int Cancer 2003; 107: 285-91.

28. Van der Waal I. Potentially malignant disorders of the oral and oropharyngeal mucosa; terminology, classification and present concepts of management. Oral Oncol 2009; 45: 317-23.

29. Yellowitz JA, Horowitz AM, Drury TF, et al. Survey of us dentists'knowledge and opinions about oral pharyngeal cancer. JADA 2000; 131: 653-61.

30. Hasanoğlu Erbaşar GN, Alpaslan C. Oral cancer prevention and early detection awareness of Ankara dentists. Acta Oncol Tur 2017; 50: 139-47.

31. Kujan O, Duxbury A, Glenny A, et al. Opinions and attitudes of the UK's GDPs and specialists in oral surgery, oral medicine and surgical dentistry on oral cancer screening. Oral Diseases 2006; 12: 194-9.
32. http://nysdflearning.org/courses.html.

33. Bayraktar Y, Bahadır HS. Assessing the oral health literacy, oral health related quality of life and oral health status in adult patients. Atatürk Univ Diş Hek Fak Deg 2020; 31: 52-8.

\author{
Sorumlu Yazarın Yazışma Adresi \\ Gurbet Alev ÖZTAŞ \\ Ataturk University Faculty of Dentistry \\ Department of Periodontology, Erzurum, \\ mobile: +90506 3279811 \\ email: alev.oztas@atauni.edu.tr
}

